\title{
$N$-Alkylated Sulfamic Acid Derivatives as Organocatalyst in Multicomponent Synthesis of Fatty Dihydropyrimidinones
}

\author{
Carolina R. L. Hack, ${ }^{a}$ Larissa Porciuncula, ${ }^{a}$ Andressa C. H. Weber, ${ }^{a}$ \\ Caroline R. M. D'Oca, ${ }^{a}$ Dennis Russowsky, ${ }^{b}$ Jaqueline M. Moura, ${ }^{c}$ \\ Luiz A. A. Pinto ${ }^{c}$ and Marcelo G. M. D'Oca ${ }^{*, a}$ \\ ${ }^{a}$ Laboratório Kolbe de Síntese Orgânica, Universidade Federal do Rio Grande, \\ Av. Itália, km 08 s/n, 96203-900 Rio Grande-RS, Brazil \\ ${ }^{b}$ Laboratório de Síntese Orgânica, Universidade Federal do Rio Grande do Sul, \\ Av. Bento Gonçalves 9500, 91501-970 Porto Alegre-RS, Brazil \\ 'Laboratório de Operações Unitárias, Universidade Federal do Rio Grande, \\ Av. Itália, km 08 s/n, 96203-900 Rio Grande-RS, Brazil
}

\begin{abstract}
In this work, $N$-alkylated sulfamic acid derivatives are introduced as promising acidic organocatalysts with convenient acidity and easy synthesis. The new organocatalysts derived from different nitrogenated compounds (amines, chitosan, urea and thiourea) were applied in multicomponent reactions to synthesize several dihydropyrimidinones (DHPMs). All tested organocatalysts resulted in good DHPM yields, using classic 1,3-dicarbonyl compounds and long-chain 1,3-dicarbonyl derivatives, demonstrating catalytic efficiency. $\mathrm{N}$-Alkylated sulfamic acid derived from benzylamine showed good results (ca. 80\% yields). In addition, excellent results were obtained with organocatalysts based on sulfamic acid and thiourea (ca. 80-97\% yields), demonstrating the catalytic efficiency of new derivatives of thiourea organosulfamic catalysts.
\end{abstract}

Keywords: sulfamic acid, organocatalysts, Biginelli reaction, multicomponent reaction, fatty derivatives

\section{Introduction}

Organocatalysis is a field of organic chemistry in constant growing and several organocatalysts have been developed for different organic reactions. The first mention date to back the second decade of $20^{\text {th }}$ century from the Bredig and Fiske's report ${ }^{1}$ using some alkaloids as catalysts in the addition reaction of hydrocyanic acid to benzaldehyde. Organocatalytic methods has been currently widely applied in the synthesis of various bioactive compounds including large-scale intermediates in the pharmaceutical industry. ${ }^{2}$ The main advantage is due to avoiding contamination risk by metals. ${ }^{3}$ In addition, the organocatalysts are generally cheap, stable in atmospheric conditions, allow reproducible results and require simple reaction conditions. ${ }^{4}$

Sulfamic acid $\left(\mathrm{SA}, \mathrm{H}_{2} \mathrm{NSO}_{3} \mathrm{H}\right)$ has emerged as a substitute for conventional Bronsted and Lewis acid catalysts in organic

*e-mail: dqmdoca@furg.br synthesis. ${ }^{5}$ It is a relatively stable, white crystalline and odorless solid, non-volatile, non-hygroscopic, non-corrosive, and inexpensive. ${ }^{6}$ In addition, it is a heterogeneous catalyst, and can be recovered by simple filtration and is considered an efficient green catalyst. ${ }^{7,8}$ It has been used in acid catalyzed reactions, for functional group protections ${ }^{8}$ and deprotections, ${ }^{9}$ and some important organic transformations, such as the Beckmann rearrangement, ${ }^{10}$ Michael addition, ${ }^{11}$ imino Diels-Alder, ${ }^{12}$ Pechmann reaction, ${ }^{13}$ esterifications, ${ }^{14}$ transesterification, ${ }^{15}$ Hantzsch reaction ${ }^{16}$ and Biginelli condensations. ${ }^{17}$ According to a previous study, ${ }^{18}$ the $\mathrm{p} K_{\mathrm{a}}$ of SA in water is 1.19. As would be expected, the aliphatic derivatives of SA are weaker acids than SA itself. For example: the $\mathrm{p} K_{\mathrm{a}}$ value for cyclohexylsulfamic acid was found to be $1.90 .{ }^{19}$ Dupont et al. ${ }^{20}$ synthesized recently different $N$-alkylated sulfamic acid (NSA) as acidic metal extractants ( $K_{\mathrm{a}}$ ca. 2 ). Other species such as $N$-alkylated sulfamic acid ionic liquids $\left(\left[\mathrm{R}_{2} \mathrm{NH}-\mathrm{SO}_{3} \mathrm{H}\right]\left[\mathrm{Tf}_{2} \mathrm{~N}\right]\right)$ were presented as a new and safe to handle class of super acids $\left(\mathrm{p} K_{\mathrm{a}}\right.$ value $\left.<-7\right) .{ }^{20}$ The $N$-alkylated sulfamic acid derivatives 
showed a good miscibility in various organic solvents such as methanol, ethanol and acetone. This fact turns its use in organic media compatible and interesting to apply as a promoter in organic reactions.

In the present work, we describe the synthesis of new $N$-alkylated sulfamic acid derivatives and their uses as organocatalysts in multicomponent Biginelli reactions to achieve the synthesis of dihidropirimidin-2-ones and their respective fatty derivatives following up the research previously developed in our research group. ${ }^{21}$

\section{Results and Discussion}

A series of $N$-alkylated sulfamic acid derivatives NSA 01-06 was synthesized using a set of primary amines and chlorosulfonic acid, according to a procedure described in the literature (Scheme 1). ${ }^{22}$ The NSA 01-06 organocatalysts were characterized by melting point, and infrared (IR), nuclear magnetic resonance (NMR), and high resolution mass spectrometries (HRMS).

Initially, the Biginelli reaction was carried out reacting methyl acetoacetate, benzaldehyde and urea in the presence of $10 \mathrm{~mol} \%$ of SA as pattern, under reflux of methanol. ${ }^{23}$ The reaction was monitored by thin-layer chromatography (TLC) and the aldehyde consumption was observed after $4 \mathrm{~h}$. In this case, the dihydropyrimidinone 1 was formed in $84 \%$ yield. The result is shown in Table 1 (entry 2).

Next, we examined the ability of NSA's as organocatalysts to promote the Biginelli reaction. The loading of 10 or $20 \mathrm{~mol} \%$ of NSA 01-06 were investigated under the same experimental conditions (Scheme 2). The dihydropyrimidinone $\mathbf{1}$ was formed in good yields in all examined cases (Table 1, entries 3-14). The best catalytic behavior was observed when $20 \mathrm{~mol} \%$ of organocatalyst NSA 04 was employed (Table 1, entry 10).

As a part of our ongoing efforts to synthesize new fatty hybrid molecules, we applied this protocol to the synthesis of hybrid fatty dihydropyrimidinones (fatty-DHPMs). ${ }^{16,21,24}$ Thus, the multicomponent Biginelli reaction was performed in the presence of long-chain octadecyl acetoacetate $\mathbf{2 c},{ }^{24}$ benzaldehyde, urea and $20 \mathrm{~mol} \%$ of NSA 01-06 under reflux of methanol. In these cases, $24 \mathrm{~h}$ were necessary to complete the reactions (Scheme 3). The crude product was purified by column chromatography and characterized by

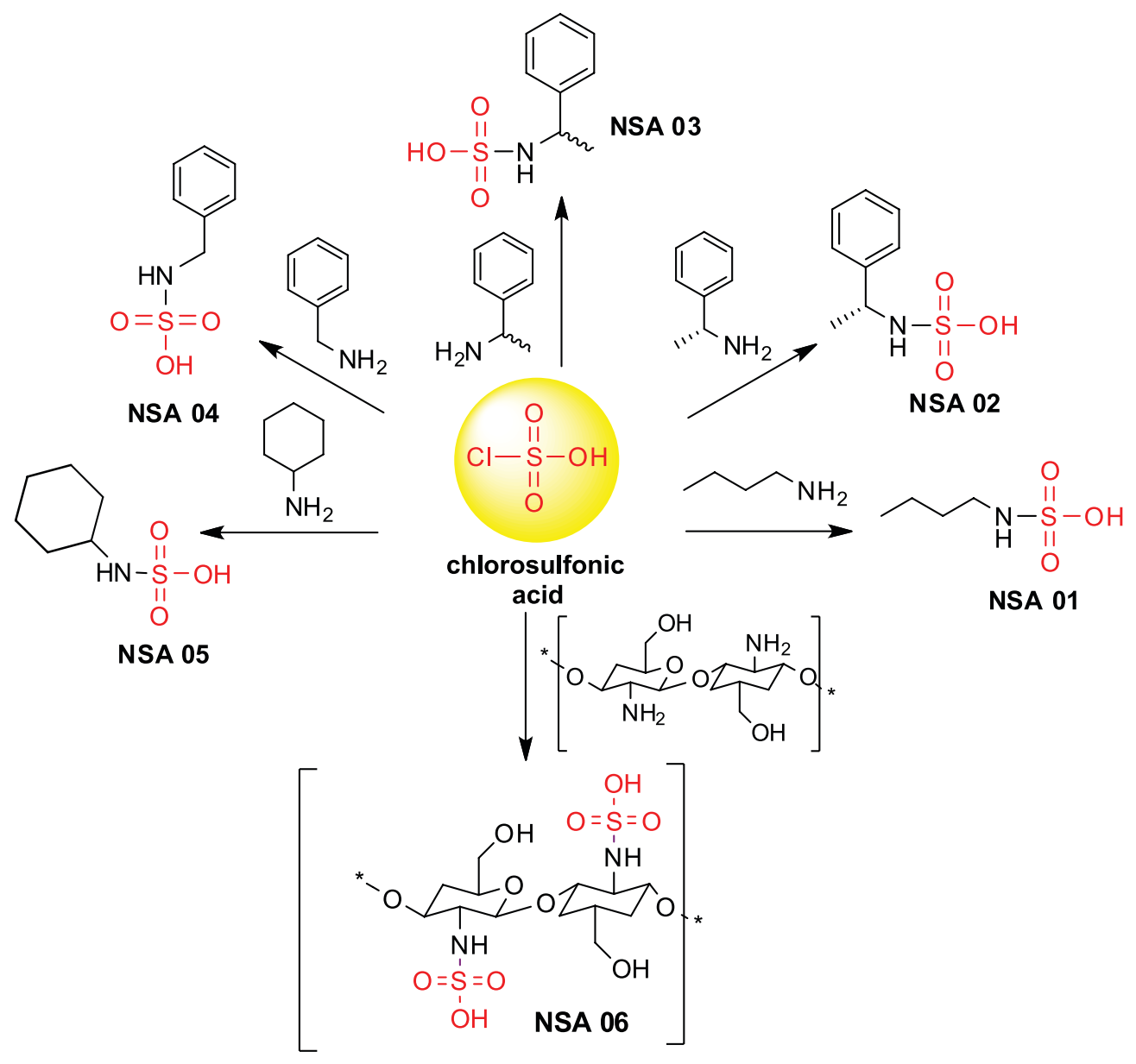

Scheme 1. Synthesis of $N$-alkylated sulfamic acid organocatalysts NSA 01-06. 
Table 1. Multicomponent synthesis of DHPM 1 using SA and organocatalysts NSA 01-06

\begin{tabular}{lccc}
\hline entry & Catalyst & Catalyst / mol\% & 1, Yield / \% \\
\hline 1 & - & - & 9 \\
2 & $\mathrm{NH}_{2} \mathrm{SO}_{3} \mathrm{H}$ & 10 & 84 \\
3 & NSA 01 & 10 & 57 \\
4 & NSA 01 & 20 & 75 \\
5 & NSA 02 & 10 & 49 \\
6 & NSA 02 & 20 & 68 \\
7 & NSA 03 & 10 & 54 \\
8 & NSA 03 & 20 & 67 \\
9 & NSA 04 & 10 & 63 \\
10 & NSA 04 & 20 & 79 \\
11 & NSA 05 & 10 & 45 \\
12 & NSA 05 & 20 & 65 \\
13 & NSA 06 & 10 & 59 \\
14 & NSA 06 & 20 & 67 \\
\hline
\end{tabular}

IR, ${ }^{1} \mathrm{H}$ and ${ }^{13} \mathrm{C}$ NMR spectroscopies. ${ }^{23,24}$ The results are showed in Table 2. The fatty-DHPM 1c was formed in good yields, with NSA 04 and NSA 01 catalysts showing the most relevant results (Table 2, entries 2 and 5, respectively).

Although the yield of reactions involving the NSA 06 catalyst, derived from chitosan, were modest (Table 1, entries 13-14 and Table 2, entry 7), they could be considered relevant, since the chitosan is easily obtained from natural resources and is a low-cost material. ${ }^{25}$

To increase the scope of products obtained through this process, we utilized long-chain alkyl acetoacetates derived from fatty alcohols, combined with urea or thiourea and<smiles>COC(=O)CC(C)=O</smiles>

Table 2. Synthesis of fatty DHPM 1c using SA and organocatalysts NSA 01-06

\begin{tabular}{lccc}
\hline entry & Catalyst & Catalyst / mol\% & 1c, Yield / \% \\
\hline 1 & $\mathrm{NH}_{2} \mathrm{SO}_{3} \mathrm{H}$ & 20 & 74 \\
2 & $\mathbf{N S A ~ 0 1}$ & 20 & 79 \\
3 & $\mathbf{N S A ~ 0 2}$ & 20 & 56 \\
4 & $\mathbf{N S A ~ 0 3}$ & 20 & 53 \\
5 & $\mathbf{N S A ~ 0 4}$ & 20 & 80 \\
6 & $\mathbf{N S A ~ 0 5}$ & 20 & 72 \\
7 & NSA 06 & 20 & 53 \\
\hline
\end{tabular}

several aromatic aldehydes. After reactions using $20 \mathrm{~mol} \%$ of catalyst NSA 04, the fatty dihydropyrimidinones 1-6a-d were obtained (Scheme 4). All tested examples resulted in good fatty dihydropyrimidinones yields, demonstrating the catalytic efficiency of the new aminosulfamic organocatalysts NSA 04 derived from benzylamine in the multicomponent Biginelli reaction (Table 3).

In recent decades, interest has arisen in the development of organocatalysts based on mono or bifunctional urea or thiourea capable of double hydrogen bonding. A broad variety of monofunctional and bifunctional achiral double hydrogen-bonding thiourea organocatalysts have been developed to accelerate various synthetically useful organic transformations employing H-bond-accepting substrates (Figure 1). ${ }^{26}$

A recent report of Puripat et al..$^{27}$ based on computational calculations, suggested that urea would be a good catalyst for the synthesis of 3,4-dihydropyrimidinones via Biginelli reaction. Taking this into account, we decided to investigate

Scheme 2. Synthesis of DHPM 1 using aminosulfamic organocatalysts NSA 01-06.

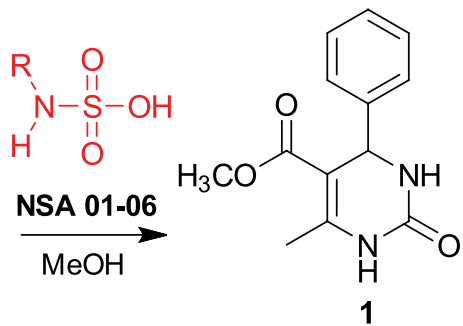<smiles>O=Cc1ccccc1</smiles><smiles>CC(=O)CC(=O)OCCCCCCCCC(N)=O</smiles><smiles>[R]NS(=O)(=O)OCCCC</smiles>

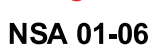<smiles>COC(C)C(C)(C)O</smiles><smiles>CCCOC(=O)C1=C(C)NC(=O)NC1c1ccccc1</smiles>

Scheme 3. Synthesis of fatty DHPM 1c under catalysis with NSA 01-06. 


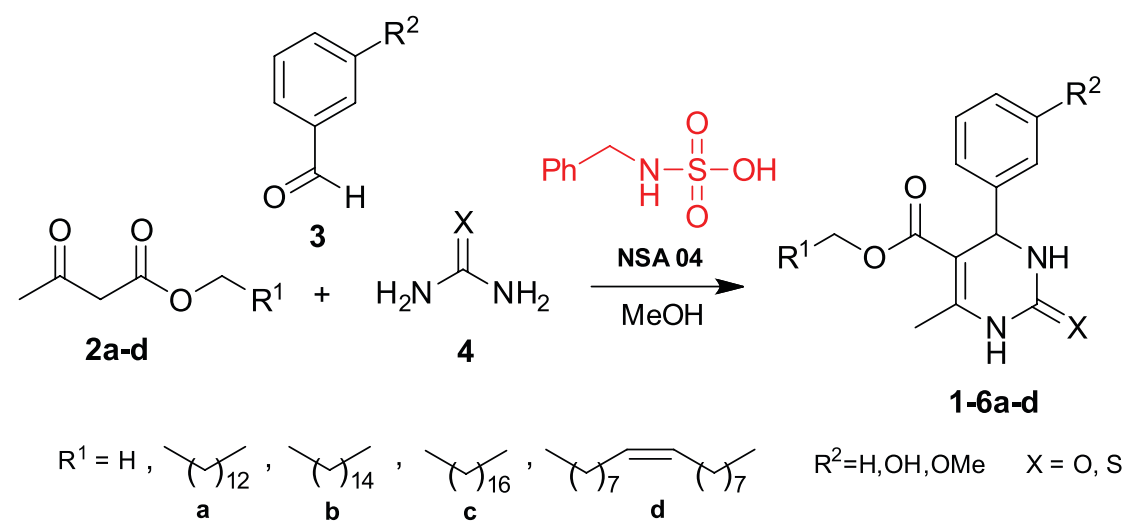

Scheme 4. Synthesis of long chain DHPMs 1-6a-d under catalysis with NSA 04.

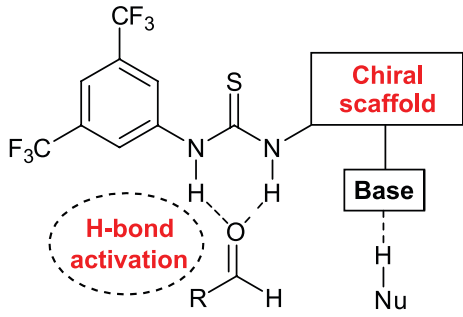

Figure 1. Bifunctional organocatalysts based on thiourea.

Table 3. Synthesis of fatty DHPMs 1-6a-d using organocatalyst NSA 04

\begin{tabular}{|c|c|c|c|c|}
\hline entry & $\mathrm{R}^{1}$ & $\mathrm{R}^{2}$ & $\mathrm{X}$ & Yield / \% \\
\hline 1 & & $\mathrm{H}$ & $\mathrm{O}$ & 1a, 89 \\
\hline 2 & & $\mathrm{OH}$ & $\mathrm{O}$ & $\mathbf{2 a}, 86$ \\
\hline 3 & & $\mathrm{OMe}$ & $\mathrm{O}$ & 3a, 80 \\
\hline 4 & & $\mathrm{H}$ & $\mathrm{O}$ & 1b, 70 \\
\hline 5 & & $\mathrm{OH}$ & $\mathrm{O}$ & $\mathbf{2 b}, 87$ \\
\hline 6 & & $\mathrm{OMe}$ & $\mathrm{O}$ & $3 \mathbf{b}, 82$ \\
\hline 7 & & $\mathrm{H}$ & $\mathrm{O}$ & 1c, 80 \\
\hline 8 & & $\mathrm{OH}$ & $\mathrm{O}$ & $2 c, 68$ \\
\hline 9 & & $\mathrm{OMe}$ & $\mathrm{O}$ & $3 c, 81$ \\
\hline 10 & & $\mathrm{H}$ & $\mathrm{O}$ & 1d, 87 \\
\hline 11 & & $\mathrm{OH}$ & $\mathrm{O}$ & 2d, 84 \\
\hline 12 & & $\mathrm{OMe}$ & $\mathrm{O}$ & 3d, 83 \\
\hline 13 & & $\mathrm{H}$ & $\mathrm{S}$ & $\mathbf{4 a}, 82$ \\
\hline 14 & & $\mathrm{OH}$ & $\mathrm{S}$ & $\mathbf{5 a}, 84$ \\
\hline 15 & & $\mathrm{OMe}$ & $\mathrm{S}$ & $\mathbf{6 a}, 76$ \\
\hline 16 & & $\mathrm{H}$ & $S$ & $4 b, 87$ \\
\hline 17 & & $\mathrm{OH}$ & $\mathrm{S}$ & $\mathbf{5 b}, 65$ \\
\hline 18 & & $\mathrm{OMe}$ & $\mathrm{S}$ & $6 \mathbf{b}, 62$ \\
\hline 19 & & $\mathrm{H}$ & $\mathrm{S}$ & $\mathbf{4 c}, 81$ \\
\hline 20 & & $\mathrm{OH}$ & S & $5 \mathbf{c}, 61$ \\
\hline 21 & & $\mathrm{OMe}$ & S & 6c, 65 \\
\hline 22 & & $\mathrm{H}$ & $\mathrm{S}$ & $4 d, 70$ \\
\hline 23 & & $\mathrm{OH}$ & $\mathrm{S}$ & 5d, 76 \\
\hline 24 & & $\mathrm{OMe}$ & $\mathrm{S}$ & 6d, 66 \\
\hline
\end{tabular}

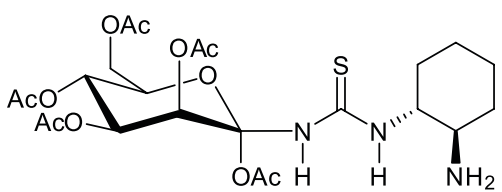

Asymmetric catalyst of the Biginelli reaction (15-99 ee\%) 


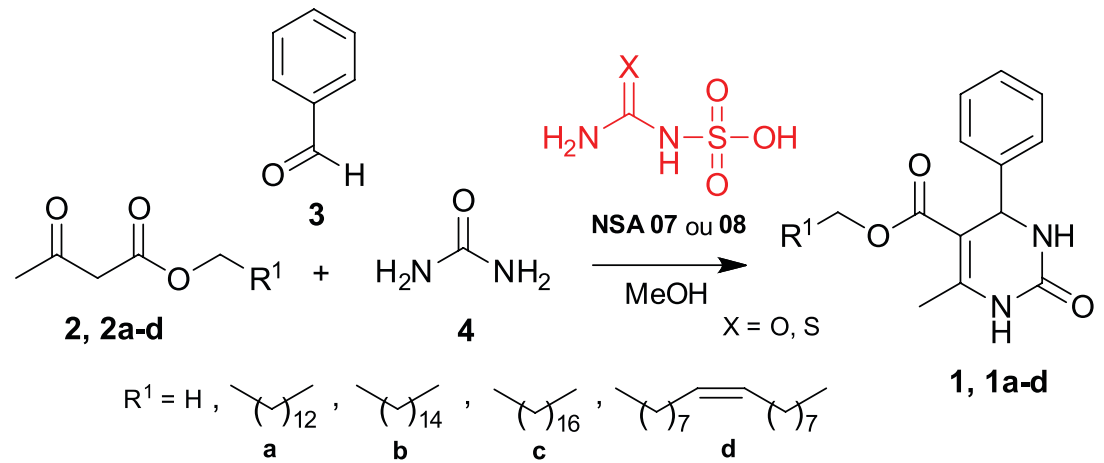

Scheme 6. Organocatalytic properties of NSA 07 and NSA 08 in Biginelli reaction.

Table 4. Synthesis of DHPM 1, 1a-d under catalysis of NSA 07 and NSA 08

\begin{tabular}{|c|c|c|c|c|c|}
\hline entry & $\mathrm{R}^{1}$ & Catalyst & Catalyst / mol\% & time $/ \mathrm{h}$ & Yield / \% \\
\hline 1 & $-\mathrm{CH}_{3}$ & \multirow{10}{*}{ NSA 07} & 10 & 5 & $\mathbf{1}, 47$ \\
\hline 2 & $-\mathrm{CH}_{3}$ & & 20 & 5 & 1,54 \\
\hline 3 & $-\mathrm{CH}_{3}$ & & 10 & 6 & 1,52 \\
\hline 4 & $-\mathrm{CH}_{3}$ & & 20 & 6 & 1,65 \\
\hline 5 & $-\mathrm{CH}_{3}$ & & 10 & 8 & 1,57 \\
\hline 6 & $-\mathrm{CH}_{3}$ & & 20 & 8 & 1,67 \\
\hline 7 & & & 20 & 24 & $1 \mathbf{a}, 51$ \\
\hline 8 & & & 20 & 24 & 1b, 57 \\
\hline 9 & & & 20 & 24 & 1c, 61 \\
\hline 10 & & & 20 & 24 & $1 d, 65$ \\
\hline 11 & $-\mathrm{CH}_{3}$ & \multirow{8}{*}{ 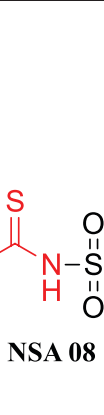 } & 10 & 5 & 1,74 \\
\hline 12 & $-\mathrm{CH}_{3}$ & & 20 & 5 & $\mathbf{1}, 87$ \\
\hline 13 & $-\mathrm{CH}_{3}$ & & 10 & 6 & $\mathbf{1}, 80$ \\
\hline 14 & $-\mathrm{CH}_{3}$ & & 20 & 6 & $\mathbf{1}, 81$ \\
\hline 15 & $-\mathrm{CH}_{3}$ & & 10 & 8 & 1,84 \\
\hline 16 & $-\mathrm{CH}_{3}$ & & 20 & 8 & $\mathbf{1}, 88$ \\
\hline 17 & T & & 20 & 24 & 1a, 97 \\
\hline 18 & & & 20 & 24 & $\mathbf{1 b}, 91$ \\
\hline 19 & ()$_{16}$ & & 20 & 24 & $1 c, 82$ \\
\hline 20 & & & 20 & 24 & 1d, 93 \\
\hline
\end{tabular}

with organocatalysts NSA 07 and NSA 01-06 (Table 2, entries 2-7).

Figure 2 shows the ${ }^{1} \mathrm{H}$ NMR spectra of new sulfamic organocatalysts NSA 08 and thiourea precursor. The spectrum of NSA 08 indicates the disappearance of singlet in $7.05 \mathrm{ppm}$ from $\mathrm{NH}_{2}$ of thiourea and the appearance of a singlet in $1.78 \mathrm{ppm}$, attributed to $\mathrm{OH}$ and $\mathrm{NH}$ hydrogens present in the catalyst structure. In addition, two broad singlets are observed, referent to hydrogens $\mathrm{NH}_{2}$ and $\mathrm{NH}_{2}{ }^{+}$from neutral and zwitterionic forms, with $\delta 9.07$ and $5.92 \mathrm{ppm}$, respectively (Figure 2b).
The literature suggests that the catalytic behavior of sulfamic acid and derivatives is associated to the presence of zwitterion. ${ }^{20,28}$ Thus, according to ${ }^{1} \mathrm{H}$ NMR spectra (Figure 2b), the results obtained with NSA 08 could be related to the presence of zwitterion in approximately $70 \%$, showing superior catalytic activity.

\section{Conclusions}

In this work, $N$-alkylated sulfamic acid (NSA) derivatives are introduced as promising acidic organocatalysts with 

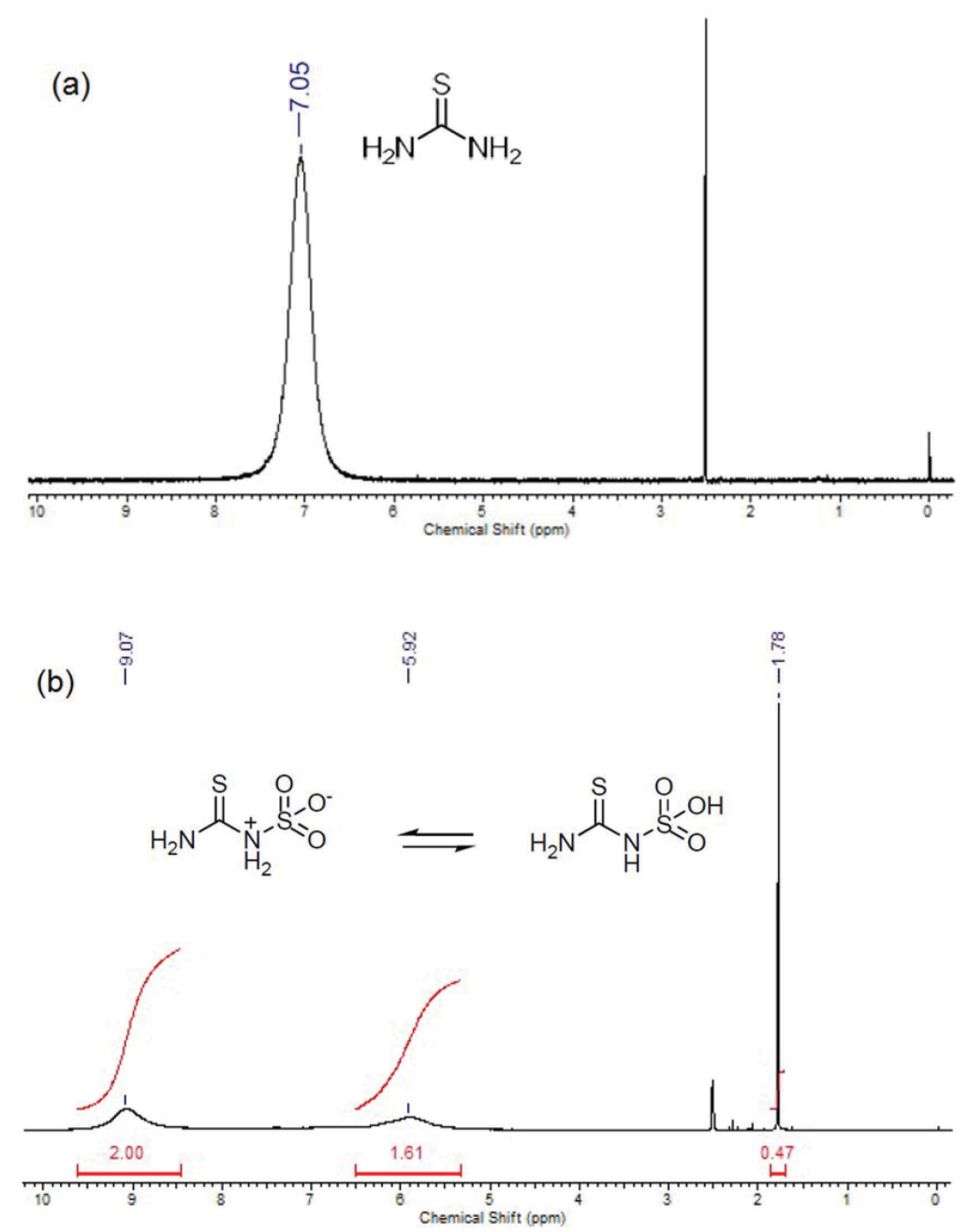

Figure 2. ${ }^{1} \mathrm{H}$ NMR (400 MHz, DMSO- $d_{6}$ ) spectra of thiourea (a) and NSA 08 (b).

convenient acidity and easy synthesis. These organocatalysts could successfully be applied in multicomponent Biginelli reaction, and good yields were observed in the synthesis of DHPMs using classic 1,3-dicarbonyl compounds and long-chain 1,3-dicarbonyl derivatives.

All tested examples resulted in good to reasonable DHPM yields, demonstrating catalytic efficiency. The $N$-alkylated aminosulfamic acid catalysts NSA 04 and NSA 01 derived from benzylamine and butylamine, respectively, showed the most relevant results. In addition, excellent results were obtained with organocatalysts NSA $\mathbf{0 8}$ based on the structure of sulfamic acid and thiourea with good yields (80-97\%), demonstrating, for the first time, its catalytic efficiency in multicomponent Biginelli reaction.

\section{Experimental}

Apparatus and chemistry

The reagents were purchased from Aldrich Chemical
Co. and used without further purification. Column chromatography was performed using a silica gel 60A (ACROS Organics, 0.035-0.070 mesh). The reactions were monitored using thin-layer chromatography (TLC) performed with plates containing silica gel (Merck, 60GF245), gradients of hexane:ethyl acetate as eluents, and the spots were visualized using iodine. The melting points were obtained on a Fisatom 430D apparatus and are uncorrected. Infrared (IR) spectra were measured on a Shimadzu PRESTIGIE-21 FT-IR spectrophotometer. Nuclear magnetic resonance experiments for ${ }^{1} \mathrm{H},{ }^{13} \mathrm{C}$ and ${ }^{15} \mathrm{~N}$ nuclei were conducted using a Bruker Ascend $400 \mathrm{MHz}$ spectrometer, equipped with $\mathrm{BBO}$ probe with z-axis gradients in $\mathrm{CDCl}_{3}, \mathrm{DMSO}-d_{6}$ or $\mathrm{CD}_{3} \mathrm{CN}$. Chemical shifts are reported in $\delta$ (ppm) downfield from the tetramethylsilane (TMS) internal standard or residual solvent. ${ }^{15} \mathrm{~N}$ data were acquired from ${ }^{1} \mathrm{H}-{ }^{15} \mathrm{~N}$ HMBC (heteronuclear multiple bond correlation) experiments at room temperature. Coupling constants $(J)$ are reported in $\mathrm{Hz}$ and refer to apparent peak multiplicities. 
General procedure for synthesis of catalysts NSA 01-05, NSA 07 and NSA 08

To a round-bottom flask containing nitrogenated compound ( $1 \mathrm{mmol}$, amine, urea or thiourea) in dry acetonitrile $(3 \mathrm{~mL})$, it was added chlorosulfonic acid ( $1 \mathrm{mmol}$ ) dropwise over a period of $20 \mathrm{~min}$ at room temperature. The reactional mixture was stirred for $2 \mathrm{~h}$, and the acetonitrile was removed under vacuum to give the catalysts.

\section{Butylsulfamic acid (NSA 01)}

$153.04 \mathrm{~g} \mathrm{~mol}^{-1}$; colorless oil; FTIR $(\mathrm{KBr}) \vee / \mathrm{cm}^{-1}$ 3516, 2962, 1597, 1496, 1465, 1220, 1058, 869; ${ }^{1} \mathrm{H}$ NMR $\left(400 \mathrm{MHz}, \mathrm{DMSO}-d_{6}\right) \delta 7.69(\mathrm{sl}, 2 \mathrm{H}), 2.77(\mathrm{~m}, 2 \mathrm{H}), 1.51$ (q, $J 8 \mathrm{~Hz}, 2 \mathrm{H}), 1.32$ (q, $J 8 \mathrm{~Hz}, 2 \mathrm{H}), 0.89(\mathrm{t}, J 4 \mathrm{~Hz}$, $8 \mathrm{H}) ;{ }^{13} \mathrm{C}$ NMR $\left(100 \mathrm{MHz}\right.$, DMSO- $\left.d_{6}\right) \delta 13.9,19.5,29.5$, 39.1; HRMS calcd. to $\mathrm{C}_{4} \mathrm{H}_{11} \mathrm{NO}_{3} \mathrm{~S}_{\left[\mathrm{M}^{-}\right]}$152.0381; found 152.0381 .

\section{(R)-1-Phenylethylsulfamic acid (NSA 02)}

$201.04 \mathrm{~g} \mathrm{~mol}^{-1}$; yellow viscous liquid; FTIR (KBr) $v / \mathrm{cm}^{-1} 3460,2868,1764,1517,1452,1087,887 ;{ }^{1} \mathrm{H}$ NMR $\left(400 \mathrm{MHz}, \mathrm{DMSO}-d_{6}\right) \delta 1.48(\mathrm{~d}, J 8 \mathrm{~Hz}, 3 \mathrm{H}), 4.41(\mathrm{sl}, 9 \mathrm{H})$, $7.45(\mathrm{~m}, 5 \mathrm{H}), 8.30(\mathrm{sl}, 2 \mathrm{H}) ;{ }^{13} \mathrm{C} \mathrm{NMR}\left(100 \mathrm{MHz}\right.$, DMSO- $\left.d_{6}\right)$ $\delta 21.2,50.5,127.2(2 \mathrm{C}), 128.9,129.2(2 \mathrm{C}), 139.7$; HRMS calcd. to $\mathrm{C}_{8} \mathrm{H}_{11} \mathrm{NO}_{3} \mathrm{~S}\left[\mathrm{M}^{-}\right]$200.0381; found 200.0372.

\section{1-Phenylethylsulfamic acid (NSA 03)}

$201.04 \mathrm{~g} \mathrm{~mol}^{-1}$; yellow viscous liquid; FTIR (KBr) $v / \mathrm{cm}^{-1} 3523,3062,1598,1510,1292,887$; ${ }^{1} \mathrm{H}$ NMR $\left(400 \mathrm{MHz}, \mathrm{DMSO}-d_{6}\right) \delta 1.50(\mathrm{~d}, J 8 \mathrm{~Hz}, 3 \mathrm{H}), 4.26(\mathrm{~m}$, $11 \mathrm{H}), 7.48(\mathrm{~m}, 5 \mathrm{H}), 8.26(\mathrm{sl}, 3 \mathrm{H}) ;{ }^{13} \mathrm{C} \mathrm{NMR}(100 \mathrm{MHz}$, DMSO- $\left.d_{6}\right) \delta 21.2,50.5,127.2(2 \mathrm{C}), 129.0,129.2(2 \mathrm{C})$, 139.6; HRMS calcd. to $\mathrm{C}_{8} \mathrm{H}_{11} \mathrm{NO}_{3} \mathrm{~S}\left[\mathrm{M}^{-}\right]$200.0381; found 200.0372 .

\section{Benzylsulfamic acid (NSA 04)}

$187.03 \mathrm{~g} \mathrm{~mol}^{-1}$; white solid; mp $69-70{ }^{\circ} \mathrm{C}$; FTIR (KBr) $v / \mathrm{cm}^{-1} 3600,3018,1591,1473,1215,1050,887 ;{ }^{1} \mathrm{H}$ NMR $\left(400 \mathrm{MHz}, \mathrm{CD}_{3} \mathrm{CN}\right) \delta 7.39(\mathrm{~m}, 7 \mathrm{H}), 5.42(\mathrm{sl}, 2 \mathrm{H}), 4.07(\mathrm{~m}$, $2 \mathrm{H}) ;{ }^{13} \mathrm{C}$ NMR $\left(100 \mathrm{MHz}, \mathrm{CD}_{3} \mathrm{CN}\right) \delta 134.0,130.2(2 \mathrm{C})$, 129.8 (2C), 118.3, 44.5; HRMS calcd. to $\mathrm{C}_{7} \mathrm{H}_{9} \mathrm{NO}_{3} \mathrm{~S}_{\left[\mathrm{M}^{-}\right]}$ 186.0225 ; found 186.0224 .

\section{Cyclohexylmethylsulfamic acid (NSA 05)}

$173.01 \mathrm{~g} \mathrm{~mol}^{-1}$; white solid; mp 163-165 ${ }^{\circ} \mathrm{C}$; FTIR (KBr) $\mathrm{V} / \mathrm{cm}^{-1} 3616,2935,1597,1496,1226,1066,887 ;{ }^{1} \mathrm{H}$ NMR $\left(400 \mathrm{MHz}, \mathrm{DMSO}-d_{6}\right) \delta 7.75(\mathrm{sl}, 3 \mathrm{H}), 4.61(\mathrm{sl}, 7 \mathrm{H}), 2.93$ $(\mathrm{m}, 1 \mathrm{H}), 1.88(\mathrm{~m}, 2 \mathrm{H}), 1.72(\mathrm{~m}, 2 \mathrm{H}), 1.56(\mathrm{~m}, 1 \mathrm{H}), 1.24$ $(\mathrm{m}, 4 \mathrm{H}), 1.08(\mathrm{~m}, 1 \mathrm{H}) ;{ }^{13} \mathrm{C}$ NMR (100 MHz, DMSO- $d_{6}$ ) $\delta$ 24.2, 25.0, 30.7, 49.8; HRMS calcd. to $\mathrm{C}_{6} \mathrm{H}_{7} \mathrm{NO}_{3} \mathrm{~S}\left[\mathrm{M}^{-}\right]$ 178.0538; found 178.0543.

\section{Carbamoylsulfamic acid (NSA 07)}

$139.99 \mathrm{~g} \mathrm{~mol}^{-1}$; white solid; mp 58-60 ${ }^{\circ} \mathrm{C}$; FTIR (KBr) $v / \mathrm{cm}^{-1} 1282,1354,1550.7,1728,3327 ;{ }^{1} \mathrm{H}$ NMR $\left(400 \mathrm{MHz}, \mathrm{DMSO}-d_{6}\right) \delta 1.80(\mathrm{~s}), 6.01$ (s), $6.96(\mathrm{~s})$; ${ }^{15} \mathrm{~N}$ NMR (40 MHz, DMSO- $d_{6}$ ) $\delta 22.4,112.1$; CHN calcd. to $\mathrm{CH}_{4} \mathrm{~N}_{2} \mathrm{O}_{3} \mathrm{~S}: \mathrm{C}, 8.57 ; \mathrm{H}, 2.88 ; \mathrm{N}, 19.99 \%$; found: $\mathrm{C}, 8.65$; $\mathrm{H}, 2.74 ; \mathrm{N}, 19.87 \%$.

\section{Carbamothioylsulfamic acid (NSA 08)}

$155.97 \mathrm{~g} \mathrm{~mol}^{-1}$; white solid; mp 137-140 ${ }^{\circ} \mathrm{C}$; FTIR $(\mathrm{KBr}) \mathrm{v} / \mathrm{cm}^{-1} 1217,1357,1531.4,1712.7,3280 ;{ }^{1} \mathrm{H}$ NMR $\left(400 \mathrm{MHz}, \mathrm{DMSO}-d_{6}\right) \delta 1.78(\mathrm{~s}), 5.91(\mathrm{~s}), 9.08(\mathrm{~s})$; ${ }^{15} \mathrm{~N}$ NMR (40 MHz, DMSO- $d_{6}$ ) $\delta$ 63.3, 86.6; CHN calcd. to $\mathrm{CH}_{4} \mathrm{~N}_{2} \mathrm{O}_{3} \mathrm{~S}_{2}: \mathrm{C}, 7.69 ; \mathrm{H}, 2.58 ; \mathrm{N}, 17.94 \%$; found: $\mathrm{C}, 7.96$; $\mathrm{H}, 2.59 ; \mathrm{N}, 17.62 \%$.

\section{Chitosan production}

Chitin was extracted from pink shrimp wastes (Farfantepenaeus brasiliensis) through chemical treatments, demineralization, deproteination, deodorization and depigmentation. Deacetylation of chitin was carried out with $150 \mathrm{~g}$ of chitin and $3 \mathrm{~L}$ of concentrated sodium hydroxide solution $(45 \% \mathrm{~m} / \mathrm{v})$ at $130 \pm 1{ }^{\circ} \mathrm{C}$, under constant agitation of $50 \mathrm{rpm} .{ }^{25}$

\section{Preparation of chitosan sulfonic acid NSA 06}

To a round-bottom flask containing a mixture of $5.0 \mathrm{~g}$ of chitosan and $20 \mathrm{~mL}$ of hexane was added dropwise $1.0 \mathrm{~g}$ of chlorosulfonic acid ( $9 \mathrm{mmol})$, at room temperature and magnetic stirring. After the addition was complete, the mixture was stirred for $1 \mathrm{~h}$. Then the mixture was filtered and washed with $30 \mathrm{~mL}$ of acetonitrile, and the solvent was removed under vacuum to afford chitosan sulfonic acid as a pale yellow powder.

\section{Chitosan sulfonic acid (NSA 06)}

$257.0205 \mathrm{~g} \mathrm{~mol}^{-1}$; pale yellow power; $\mathrm{mp}>250{ }^{\circ} \mathrm{C}$; FTIR (KBr) $v / \mathrm{cm}^{-1} 3577,3352,1637,1517,1207,1182$, 1014, 889; HRMS calcd. to $\mathrm{C}_{6} \mathrm{H}_{11} \mathrm{NO}_{8} \mathrm{~S}^{\left[\mathrm{M}^{-}\right]} 256.0491$; found 255.2351 .

General procedure for synthesis of fatty 3,4-dihydropyrimidin2(1H)-one/thiones (1-6a-d)

A mixture of acetoacetate $(1 \mathrm{mmol})$, aldehyde $(1 \mathrm{mmol})$, urea or thiourea $(1 \mathrm{mmol})$ in $3 \mathrm{~mL}$ methanol was refluxed 
for $24 \mathrm{~h}$ in the presence of catalyst $(0.2 \mathrm{mmol})$. The progress of the reaction was monitored by TLC (hexane/ethyl acetate 8:2). After completion of the reaction, the mixture was evaporated under reduced pressure and the crude product was recrystallized from ethyl acetate to obtain pure fatty 3,4-dihydropyrimidin-2(1H)-one/thiones according to literature. ${ }^{23,24}$

\section{Supplementary Information}

Supplementary data are available free of charge at http://jbcs.sbq.org.br as PDF file.

\section{Acknowledgments}

The authors would like to thank Coordenação de Aperfeiçoamento de Pessoal de Nível Superior (CAPES) and Conselho Nacional de Desenvolvimento Científico e Tecnológico $(\mathrm{CNPq})$ for financial support and fellowships.

\section{References}

1. Bredig, G.; Fiske, P. S.; Biochem. Z. 1913, 46, 7.

2. Jensen, K. L.; Poulsen, P. H.; Donslund, B. S.; Morana, F.; Jørgensen, K. A.; Org. Lett. 2012, 14, 1516.

3. Baran, R.; Veverková, V.; Škvorcová, A.; Sebesta, R.; Org. Biomol. Chem. 2013, 11, 7705 .

4. Verma, S.; Jain, S. L.; Sain, B.; Tetrahedron Lett. 2010, 51, 6897.

5. Heravi, M. M.; Baghernejad, B.; Oskooie, H. A.; Curr. Org. Chem. 2009, 13, 1002.

6. Kaliannan, P.; Vishveswara, S.; Rao, V. S. R.; Curr. Sci. 1985, 54, 1174; Heravi, M. M.; Ranjbar, L.; Derikvand, F.; Alimadadi, B.; Mol. Diversity 2008, 12, 191; Rostamniai, A.; Ahmad-Jangi, F.; Chin. Chem. Lett. 2011, 22, 1029.

7. Yadav, J. S.; Ather, H.; Rao, P. P.; Rao, R. S.; Nagaiah, K.; Prasad, A. R.; Catal. Commun. 2006, 7, 797.

8. Jin, T. S.; Sun, G.; Li, Y. W.; Li, T. S.; Green Chem. 2002, 4, 255.

9. Wang, B.; He, J.; Sun, R. C.; Chin. Chem. Lett. 2010, $21,794$.

10. Li, J. T.; Meng, X.-T.; Yin, Y.; Synth. Commun. 2010, 40, 1445.

11. An, L.-T.; Zou, J.-P.; Zhang, L.-L.; Zhang, Y.; Tetrahedron Lett. 2007, 48, 4297.

12. Nagarajan, R.; Magesh, C. J.; Perumal, P. T.; Synthesis 2004, $1,69$.

13. Sing, P. R.; Singh, D. U.; Samant, S. D.; Synlett 2004, 11, 1909.

14. D’Oca, M. G. M.; Marinho, R. S.; de Moura, R. R.; Granjão, V. F.; Fuel 2012, 97, 884; de Oliveira, P. M.; Farias, L. M.;
Morón-Villarreyes, J. A.; D’Oca, M. G. M.; J. Am. Oil Chem. Soc. 2016, 93, 1393.

15. Weber, A. C. H.; Batista, T. C.; Gonçalves, B.; Hack, C. R. L.; Porciuncula, L. M.; Treptow, T. G. M.; D’Oca, C. R. M.; Russowsky, D.; D’Oca, M. G. M.; J. Am. Oil Chem. Soc. 2016, 93, 1399.

16. Fontecha-Terazona, H. D.; Brinkerhoff, R. C.; Oliveira, P. M.; Rosa, S. B.; Flores, D. C.; D’Oca, C. R. M.; Russowsky, D.; D’Oca, M. G. M.; RSC Adv. 2015, 5, 59638; Cabrera, D. C.; Rosa, S. B.; de Oliveira, F. S.; Marinho, M. A. G.; D’Oca, C. R. M.; Russowsky, D.; Horn, A. P.; D’Oca, M. G. M.; Med. Chem. Commun. 2016, 7, 2167.

17. Wang, B.; Synlett 2005, 2005, 1342; Li, J.-T.; Han, J.-F.; Yang, J.-H.; Li, T.-S.; Ultrason. Sonochem. 2003, 10, 119; Chen, W. Y.; Qin, S. D.; Jin, J. R.; Synth. Commun. 2007, 37, 47.

18. Benson, G. A.; Spillane, W. J.; Chem. Rev. 1980, 80, 151.

19. Kojima, S.; Ichibagase, H.; Iguchi, S.; Chem. Pharm. Bull. 1966, 14, 965.

20. Dupont, D.; Renders, E.; Raiguel, S.; Binnemans, K.; Chem. Commun. 2016, 52, 7032.

21. Duarte, R. C.; Ongaratto, R.; Piovesan, L. A.; de Lima, V. R.; Soldi, V.; Merlo, A. A.; D’Oca, M. G. M.; Tetrahedron Lett. 2012, 53, 2454; Brinkerhoff, R. C.; Fontecha-Terazona, H. D.; de Oliveira, P. M.; Flores, D. C.; D’Oca, C. R. M.; Russowsky, D.; D’Oca, M. G. M.; RSC Adv. 2014, 4, 49556.

22. Safari, J.; Banitaba, S. H.; Khalili, S. D.; J. Mol. Catal. A: Chem. 2011, 335, 46.

23. Godoi, M. N.; Costenaro, H. S.; Kramer, E.; Machado, P. S.; D’Oca, M. G. M.; Russowsky, D.; Quim. Nova 2005, 28, 1010.

24. Treptow, T. G. M.; Figueiró, F.; Jandrey, E. H. F.; Battastini, A. M. O.; Salbego, C. G.; Hoppe, J. B.; Taborda, P. S.; Rosa, S. B.; Piovesan, L. A.; D’Oca, C. R. M.; Russowsky, D.; D’Oca, M. G. M.; Eur. J. Med. Chem. 2015, 95, 552.

25. Moura, C. M.; Moura, J. M.; Soares, N. M.; Pinto, L. A. A.; Chem. Eng. Process. 2011, 50, 351; Moura, J. M.; Farias, B. S.; Rodrigues, D. A. S.; Moura, C. M.; Dotto, G. L.; Pinto, L. A. A.; J. Polym. Environ. 2015, 23, 470.

26. Schreiner, P. R.; Wittkopp, A.; Org. Lett. 2002, 4, 217; Wang, J.; Li, H.; Yu, X.; Zu, L.; Wang, W.; Org. Lett. 2005, 7, 4293; Yamaoka, Y.; Miyabe, H.; Takemoto, Y.; J. Am. Chem. Soc. 2007, 129, 6686.

27. Puripat, M.; Ramozzi, R.; Hatanaka, M.; Parasuk, W.; Parasuk, V.; Morokuma, K.; J. Org. Chem. 2015, 80, 6959.

28. Spillane, W.; Malaubier, J.-B.; Chem. Rev. 2014, 114, 2507.

Submitted: March 21, 2018 Published online: June 11, 2018 